\title{
Examining and Understanding Transformative Learning to Foster Technology Professional Development in Higher Education
}

\author{
http://dx.doi.org/10.3991/ijet.v7i1.1764 \\ Maurice Schols \\ Fontys University of Applied Sciences, Tilburg, The Netherlands
}

\begin{abstract}
Educators are increasingly encouraged to practice life-long learning. Learning to cope with emerging technologies for educational purposes is, for most educators, a complex process. Consequently, educators engage in critical reflective processes, and consider new views as they learn new knowledge and skills so as how to best apply information and communication technologies to teaching and learning. For educators this process can be intimidating and frustrating. The use of new technologies in education requires educators to reconceptualise traditional educational concepts which means that educators need compelling reasons to dramatically change their teaching and learning practice.This paper highlights the significance of Mezirow's transformative learning theory for teachers' technology professional development and provides insight in teachers' learning processes as they learn emerging technologies for educational purposes. The data discussed in this paper have been drawn from a study at FontysUniversity of Applied Sciences, The Netherlands. The data were collected and analyzed according to a qualitative approach.
\end{abstract}

Index Terms-Transformative learning, technology professional development, higher education, emerging technologies

\section{INTRODUCTION}

Many universities, colleges and other educational institutions are continually striving to improve and provide first class educational opportunities to their students. However, over the last decades many of these institutions have experienced profound changes in their primary and secondary processes of education, research and organization. One result of these changes is that issues of teacher professionalism are contested at both the level of "policy and of practices” [1].

Teaching is becoming one of the most challenging professions in a society where modern technologies provide new educational possibilities and place more demands on educators to make use of innovative educational technologies in their teaching [2]. Educators need to examine the pedagogical potential and opportunities of information and communication technologies (ICTs) in their teaching. Moreover, educators are expected to be able to facilitate learning in a meaningful way and the use of innovative technologies has provided new means and possibilities to bring the new learning to meaningful educational application in the classroom. Consequently, educators' traditional professional development needs to be changed in structure as well as in content.
Several distinct bodies of literature on technology professional development (TPD) [3, 4] are discussed in this paper. In considering literature on TPD, it is evident that the traditional focus of discussion has been primarily on the integration of technology into the curriculum. Numerous publications on the use of information and communication technologies (ICTs) in teaching and learning provide educators with meaningful and useful ideas, concepts and guidelines $[5,6,7]$. However, most of these publications promote the professional development of educators but fall short of addressing the issues concerning how to best conduct TPD. Fullan and Stiegelbauer [8] summarized the inadequacies of traditional professional development by saying that "nothing has promised so much and has been frustratingly wasteful as the thousands of workshops and conferences that led to no significant change in practice when the teachers returned to their classrooms" [8, p.35].

The main aim of this paper is to look at Mezirow's transformative learning theory [9] in educational TPD in order to come to grips with the discrepancy between traditional approaches to professional development and TPD that are identified in literature. The key question in this paper is: whether transformative learning can foster educators' TPD.

\section{A GROWING DEMAND FOR NEW SKILLS}

As we enter the $21^{\text {st }}$ century, teaching is becoming one of the most challenging professions in a society in which technology has a great impact [10]. Educators are increasingly encouraged to practice lifelong learning. Moreover, the constant demand from ministries of education, accrediting organizations, administrations, parents and teachers themselves for professional development in the use of ICTs outpaces conventional approaches of educators' professional development and emphasizes the need for different approaches in different times.

Over the last few decades, many public and private resources have been designated to providing educational institutions with adequate ICTs (hardware and software) so that educators have the opportunities to learn and use these technologies in their teaching and learning processes. Yet, educators have realized that the use of technology in the classroom does not immediately result in innovative educational practices. As a result, educational institutions as well as the public are more and more aware of the need for TPD. King [3] states:

Therefore more recently, we are aware that teachers' professional development has been more prominently 
recognized and funded as an essential component to ensure pedagogically sound technology use in the classroom. [p.284]

With information technology, presently seen as one of the most significant challenges in education, educators are deeply affected by ICTs-related standards and requirements. Learning to cope with emerging technologies for educational purposes is, for most educators, a complex process. As a result, educators have specific needs with regard to the learning of these technologies as they are urged "to immediately and proficiently bring the new learning to significant educational application in the classrooms" [3, p.284]. Consequently, educators engage in critical reflective processes, and consider new views as they learn new knowledge and skills so as how to best apply ICTs to teaching and learning.

\section{KEYWORDS AND QUESTIONS}

For educators technology learning can sometimes be intimidating and frustrating. However, looking at teachers' TPD as much more than technology training will provide "recommendations for TPD efforts that will not only transform educators' perspectives but also their practice” [3, p.295]. This paper highlights the significance of transformative learning theory for teachers' TPD and provides insight in teachers' learning processes as they learn technology for educational purposes.

Before proceeding, it is necessary to discuss some of the key terms that are used in continuing professional development (CPD) discourses and which are related to this paper. Sachs [1] states that definitions with regard to what is professionalism "have been sites of academic and ideological struggle" and are "currently being played out in several settings and contexts" [p.150]. Sachs [1] points out there is "no singular version of what constitutes professionalism or teaching as a profession that is shared by diverse groups" such as educators, ministries of education, and academics [p.150].

Continuing with Sachs' [11] analysis of professionalism, two versions of professionalism exist: 'old' and 'new'. Additionally, Sachs [11] calls 'new' professionalism transformativeor democraticprofessionalism which has emerged "in response to political, social, economic and cultural conditions” (p14).

Research and writing has increasingly focused on teachers' professional development by using a lens of transformative learning [12, 13, 14]. Cranton [15] points out that:

Transformative learning is defined as the process by which people examine problematic frames of reference to make them more inclusive, discriminating, open, reflective, and emotionally able to change. (p36).

In other words, Mezirow'stransformative learning theory describes how adults integrate new information, perspectives or practice into their own world view as they engage in different learning processes [16]. Patricia King [3] points out that "when learners engage in opportunities to reflect on the meaning of what they are learning they may engage in evaluating their familiar values, beliefs, and assumptions" [3, p.155]. Reconsidering 'old' assumptionsand beliefs, learners may develop "new ways of understanding” [3, p.155].

While ICT is not a panacea for all educational problems, universities, colleges and other educational institu- tions are aware of the need to integrate today's technologies as being essential tools for supporting teaching and learning processes.

Universities and other educational institutions are accountable for the quality of education they provide and as a result they have to listen to the call to integrate ICTs into their curricula. Consequently, traditional educators' TPD programs need to undergo rapid changes with regard to their structure and content. Transformative learning theory "provides a rich format from which to view faculty development in educational technology and providesinsights into faculty learning” [3, p.284].

\section{DISCOURSES ON TPD}

A review of the body of literature on TPD reveals two different and apparently oppositional schools of thought. The first, 'old' or traditional approach, primarily focuses on technology integration into the curriculum by providing educators with ideas and concepts in order to guide the process of using technology to meet educational standards [5, 6, 7]. Honey \&Henriquez, [17] and Mehlinger[18] for example focus on the training and practice of educators to incorporate technology into the classroom.

The second body of literature is skeptical or critical of traditional approaches with regard to TPD for educators. Research shows that technology is being used in ways that replicate traditional instructional strategies and learning $[19,20]$. More significantly, TPD tends to be "just in case" learning rather than "just in time" learning" [4, p.85]. Macmillan, Liu \& Timmons [21] and Schrum[4] point out that those educators who have struggled to learn about educational technology have experienced that a brief exposure does not provide sufficient practice and pedagogical knowledge to incorporate educational technology into their teaching and learning, which makes traditional approaches and models of TPD less effective. King [3] goes even further and emphasizes that "the need for professional development becomes essential” but points out that substantial research in the field of TPD has fallen short of "providing a cohesive concept of educators' learning needs and development” [p.285]. For King [3, 16] and others such as Cranton [13], Mezirow [22] and Hughes [23] there is an educational promise in the use of ICT resources that are more and more available to educators which can contribute to innovative teaching and learning. Hughes [23] elaborates on this and stresses that "the goal of TPD, then, is to help teachers make meaning of new constructs and experiences" [p.285] in order to determine the impact of ICTs on education.

\section{TRANSFORMATIVELLEARNING THEORY}

Transformative learning theory is based on constructivist assumptions. Mezirow[9] sees personal meaning as constructed from our own experiences which we can validate through interaction and communication with other people. This means that what we make of the world is based on our perceptions and experiences. Mezirow[24] defines the process of learning as "the social process of constructing and appropriating a new or revised interpretation of the meaning of one's experiences as a guide to action" [24, p.222]. In fact, Mezirow [24] states that the process of learning which is meaningfulis "focused, shaped and delimited by our frames of references" and that "these meaning structures involve meaning perspectives and meaning schemes" [pp.222-223]. Meaning 
perspectives “are broad sets of predispositions” which result from "psycho-cultural assumptions which determine the horizons of our expectations" [24, p.223]. Meaning schemes, comprises the "constellation of concept, belief, judgment and feeling which shape a particular interpretation” [24, p.223]. In his discussion, Mezirow[24]) emphasizes that meaning structures are transformed through reflection and states that:

Reflection involves a critique of assumptions to determine whether the belief, often acquired through cultural assimilation in childhood, remains functional for us adults. We do this by critically examining its origins, nature, and consequences. [p.223]

Reflection is seen as a key concept of transformative learning. In other words, reflective thinking transforms meaning structures. This notion can be traced to Dewey [25], who defined reflective thinking as an "active, persistent and careful consideration of any belief or supposed form of knowledge in the light of the grounds that support it and the further conclusions to which it tends" [p.9]. Mezirow's definition of reflection does not differ from Dewey's definition and can be seen as reasoning and reinterpreting acquired knowledge and experiences to form mental structures [15]. Reflective thinking according to Mezirow's theory of transformative learning can be summarized as a process in which the learner acquires new knowledge by critically examining existing assumptions, beliefs and values. Mezirow[26] states that a reflective process begins with a "disorienting dilemma" [p.94] and he elaborates that transformative learning:

Begins when we encounter experiences, often in an emotionally charged situation, that fail to fit our expectations and consequently lack meaning for us, or we encounter an anomaly that cannot be given coherence either by learning within existing schemes or by learning new schemes. [p.94]

Mezirow [26] makes a threefold distinction with regard to reflective thinking: contentreflection, process reflection, and premise reflection. Content reflectioncomprises the process of examining the content or description of a problem. It is the equivalent of asking, What is happening here? What is the current problem? If an educator encounters a new piece of educational technology, he might ask, "What is it? What can I do with it in my classroom?" The educator could try to determine how it works or observe another educator using it. This, in general, would lead to content reflection which relates to the acquisition of technical knowledge and which Mezirow[26] defines as instrumental learning.

Process reflection involves strategies with regard to problem-solving. It asks questions of the form, Why did not I know this? or Why could this happen? In an educational context this could mean that the educator was not able to use the educational technology in his classroom. The educator might review the process or critically reflect on it by asking himself, "Did I miss something essential? Did I misinterpret what the trainer or colleague said?” In fact the educator is reflecting on the process of understanding the problem and might review the process used so far.

Premise reflection occurs when the problem itself, which the learner encounters, is questioned. It asks questions in the form, Why is this technology important to me in education? or What difference does it make when using
ICTs in my classroom? In other words, the learner reflects on "the premise or basis of the problem" [15, p.34].

Cranton[13] regards critical reflection as a central process in transformative learning which leads towards a "more inclusive, differentiated, permeable, and integrated perspective" [p.56]. It is premise reflection which has the potential to lead a learner to the transformation of "habits of mind" [22, p.263]. These habits of mind create certain limitations and are considered as "distorted meaning perspectives” [26, p.226]. Cranton[15] argues that context and process reflection may lead to a process of transformation but states that it is more premise reflection which critically transforms the learner's view of the world with regard to beliefs, assumptions and values.

In recent years, Mezirow's transformative learning theory has dominated adult learning literature but it has only recently addressed TPD $[13,27,15,28,2]$ in order to better understand theprocess whereby educators critically examine their beliefs, assumptions and values. As educators gain new knowledge and understanding, they try to integrate it into their existing "frames of reference" [24, p.223]. During this process, prior beliefs, assumptions and values are critically examined and challenged which involves transformational learning.

As has been stated earlier, educators' perspective transformations are prompted by "disorienting dilemmas" [26, p.94]. Mezirow states that this process:

begins when we encounter experiences, often in an emotionally charged situation, that fail to fit our expectations and consequently lack meaning for us, or we encounter an anomaly that cannot be given coherence either by learning within existing schemes or by learning new schemes. [p.94]

King [3] states in her research that "in a similar fashion, revised state and national standards, school administrators, accrediting organizations,professional organizations, parents, students, and the community" [p.287] demand educators learn to use and integrate ICTs into their teaching. It is this call which creates a strong demand for educators to cope with the latest educational technology and may result in educators experiencing a 'disorienting dilemma' or "trigger an event that urges them to pursue technology education” [3, p.287].

\section{CRITIQUE OF THE LITERATURE}

Transformative learning theory has been around for over 25 years [15] and has been used by many scholars from a variety of perspectives. The amount of accessible research on transformative learning has grown exponentially, due to several international conferences and journals. However, a critical analysis of the literature [29] reveals notable gaps. In this part, I draw heavily on Taylor's critical research in the field of transformative learning.

Significant is that the preponderance of research reports have Mezirow's conception of transformative learning as a foundation and Taylor states that it is exceptionally difficult to find studies which do not, at least in part, include Mezirow's theory. Taylor [29] emphasizes in his research that only a few studies "were framed within related conceptions of transformative learning" [p.174]. In other words, Taylor suggests that there is a lack of different conceptions with regard to transformative learning and that most studies are based on Mezirow's theory. How- 
ever, I do not fully agree with Taylor's critical comment since Taylor chose to review mainly those studies which referred directly to Mezirow's transformative learning theory:

Literature searches were conducted on several data bases (e.g. ERIC, Wilson, Proquest, Medline, Lumina) using criteria for selecting thestudies. Each study: (a) used the transformative learning as its primary theoretical framework. [29, p.174]

Several studies include other theoretical models [30, 31, 32]. These studies, which include related conceptions, were "read [by Taylor] in its entirety and reviewed with the analysis of each study framed within transformative learning theory" [29, p174] such as Freire [33] and Boyd \& Meyers [34]. Although Taylor includes these examples in his research, the selected studies should not belong to the body of literature of his research.

As Taylor [29] mentions in his research that transformative learning theory or related conceptions are underresearched. According to Taylor [29], the studies conducted by [3, 16, 35, 4] are only "initial efforts" (p179) which begin to shed light on the use of ICTs that needs further research. Moreover, most of the studies which look at transformative learning in relationto TPD employ qualitative research methods. Based on his review, Taylor [29] suggests pointers for further research such as more varied methods and designs in order to collect data. This would shed more light on under-researched aspects of transformative learning in educational contexts. Taylor states that there is:

A unique compatibility between action research and transformative learning. It provides a pedagogical framework for classroom teaching action research. They share similar assumptions and outcomes about teaching for change, such as a participatory approach, the emphasis on dialogue, the essentiality of a reflective process in learning. [29, p.188]

Although research methods have become more sophisticated through the use of varied designs, surveys and digital documenting techniques such as emails and portfolios, the majority of studies have a strong reliance on a traditional qualitative approach. In retrospective interviews, which are commonly employed in qualitative studies, interviewees need to recollect from memory reflective moments associated with their reflective learning. In response to this concern, initial efforts are made by Liimatainen et al. [36] who use video-taped sessions in their research which help educators with the challenge of remembering reflective moments. Moreover, the use of this form of ICT stimulates reflection and "provides further means to better understand transformative learning” [29, p.177].

Despite the abundance of studies in the field of transformative learning, key questions with regard to technology professional development continue to be underresearched. There is a great need for adequate TPD programs and a greater understanding about the educator's role when fostering transformative learning in such programs. Why do some educators refuse to participate in these programs? What can be done to reduce resistance? Moreover, Taylor [29] mentions that there is little known about "the impact of transformative learning on learners' outcomes" [p.187]. In other words, are educators more successful in changing their education? According to
Taylor [29], "evidence for support is needed" in order to advocate, that transformative learning is a "worthwhile teaching approach” [p.187].

\section{Professional Practice}

However, as has been discussed earlier, over the last two decades, many educational institutions have adopted a wide range of ICTs into their educational delivery and support processes but many of these ICT projects have been evolutionary and not revolutionary. In other words, the use of ICTs has been a process of integrating emerging technologies in old and existing practices [37]. Douglas [38] notes, that the use of blended models has not replaced the ubiquitous mode of delivery (the classroom) by other modes of delivery (virtual).

Schrum [4] states, that it is important "to look carefully at how teachers learn about" [p.85] ICTs, since they are the key to education of the future. As Collis [39] contends, it is the educator who shapes "the eventual success or lack of any computer-in-education initiative” [p.22]. In other words, should the question be posed, is TPD part of the process of transforming teaching in higher education? Cuban $[40,19]$ has done extensive research with regard to the issue of technology and the promise that it will change education in many respects. The conclusion of his research is that teaching about technology requires a different approach. Unfortunately, little has changed, since the fundamental goals and understandings of education have not changed. Bradshaw [41] states that learning about technology is "a non-trivial and a life-changing event" [p.89] which emphasizes the fact that technology-staff development is significantly different compared with traditional types of staff development. This idea is strongly supported by current research on educator's professional development:

Staff development in technology which, to date, has relied heavily on just such in-service training is not meeting teachers' needs. What teachers really need to develop as professionals is help and supporting integrating new knowledge and skills into their classroom practice. [42, p248]

The use of ICTs in education requires educators to reconceptualise traditional educational concepts [43]. This means that educators need compelling reasons to dramatically change their teaching and learning practice. Forced or mandated changes, too often result in anger and frustration. If one is lucky the result of any technology training may be a tenuous acceptance without a real change [44]. Moreover, in many cases ICTs training for educational purposes tends to be "just in case" learning instead of "just in time" learning [4, p.85]. Schrum [4] states that "authentic reasons from their daily lives might produce educators to experiment” (p.85) with ICTs for particular educational purposes. This authentic approach is reflected in the Dutch policy document e-learning in higher education [45]. According to this policy document, the use of "just in time” [4] learning might contribute to a significant change in practice. Educators need to identify their current needs and interests which will create a certain ownership of the learning process. Identifying interests and needs "supports supplementing teachers' strengths and encourages diversified instructional strategies" [4, p.85]. The process of identifying needs and interests is a prerequisite to gear adequate technology training to educators' needs and 
perceived goals which supports educators' ownership with regard to their TPD.

There are many educators for whom the use of ICTs for educational purposes is unfamiliar and, sometimes, a daunting prospect. To most of these teachers, the use and integration of technology in their teaching requires them to assume a learning stance. Borko\& Putnam [46] state that from a constructivist perspective, "teacher-learners" engage in learning that is a "constructive and iterative process in which the teachers interpret events on the basis of existing knowledge, beliefs, and dispositions" [p.47]. With regard to educators' TPD, this means that educators should be provided with adequate training so as to help them to "make meaning of new constructs and experiences to determine its impact on education, including learning processes" [47, pp.278-279], only then educators may be willing to use ICTs for innovative teaching activities.

Fontys University of Applied Sciences' stated mission is to foster innovation in teaching and learning which is "expressed through practical lessons, practical placements and the use of modern communication technologies" [48]. Fontys is a learning community and encourages faculty members to gain more ICTs skills and knowledge. Many of the computer training initiatives are skills-based and directive in nature. In this way Fontys hopes that such "learning experiences will change teachers' practice in that they are better prepared to integrate" [47, p.279] ICTs in their teaching. However, Bransford\& Schwartz (1999) state that in learning situations, educators interpret, question, or evaluate new knowledge through previously acquired knowledge and experiences. This reflects Mezirow's[9] transformation learning theory which conceptualizes and describes learning as a process of critical reflection. In other words, educators who learn about technology should be invited to engage in opportunities to reflect on the meaning of the use of ICTs in education. Transformation learning should be voluntary and self-direction for educators is required to go into a critical questioning of beliefs, assumptions, and perspectives with regard to their TPD.

In addition to Bransford\& Schwartz' [49] research, Borko and Putnam [46] state that, "an important part of teachers' life-long learning, is the expansion of their knowledge base" [p.47]. In other words, it is strategic to identify the relevant knowledge base that educators "draw on and develop when learning to teach with technology" [47, p.279]. However, in most technology training sessions no attention is paid to the personal needs and views of the participants. Offering educators authentic reasons from their own daily lives to learn to use technology and connect it to their own subject matter knowledge and pedagogical content knowledge will encourage them to experiment with ICTs in teaching. Too often a "one size fits all” [4, p.85] model is used.

\section{EDUCATORS’ LEARNING EXPERIENCES}

The data discussed in this paper have been drawn from a study which took place at Teachers College Tilburg, Fontys University of Applied Sciences, The Netherlands. Data were gathered from a focus group interview and individual interviews which were based on the interview guide approach.All interviews lasted 20 minutes and were recorded using a laptop with an integrated microphone.
Each interview was transcribed verbatim by the researcher.

As evident from their personal interviews, educators indicated that ICT challenged their perspective of how they teach. Several colleagues, who participated in a workshop about the use of emerging educational technologies, reported that latter were challenging them to reflect on their role as educator. In other words, ICTs changed their perspective of their profession. In fact, some educators had undergone perspective transformation since most of them realized that their role as educator had expanded as they realized educational possibilities in their classroom:

I am amazed at the possibilities of using a wiki for my syntax classes. In fact my view of using wikis in the classroom has changedradically.Ireally see the benefitsof integrating wikis in constructing knowledge.(educator 1)

Another participant, who is a self-confessed technophobe and who regarded himself as a traditional teacher stated that:

The role of us educators has changed - I think for the better since the teacher has become a facilitator in a technology-equipped classroom. The traditional, authoritative approach no longer works - Teachers and students embark on a journey of endless possibilities.(educator2)

Moreover, several participants of the workshop reported that the use of ICTs in their classroom changed their perspective of education.The possibilities ofincorporating online resources changed their education from a traditional view of teaching and learning to an augmented concept of education:

The use of web 2.0 applications, which were used in the workshop, leads to more collaborative learning outside the classroom. Critical friends in a wiki will encourage students to reflect on their work and that in turn enhances their learning. In my classroom wikis willbecome the standard. (educator 3)

What is interesting about all these comments is that participants began to see their profession as having a greater scope. Teaching with ICTs is not classroom-bound but takes on a new dimension that challenges their prior restricted views, beliefs and perspectives. These observations are parallel to Mezirow[24] and Cranton's [15] transformative learning theory:

We resist learning anything that does not comfortably fit our meaning structures, but we have a strong urgent need to understand themeaning of our experience so that, given the limitations of our meaning structures, we strive toward viewpoints which are morefunctional: more inclusive, discriminating andintegrative of our experience. [24, p.223]

Educators' accounts reveal not only a change in perspective about the use of ICTs in educational contexts, but also show that they have more influence on self-directed learning:

I had some stage fright using ICTs in my classroom but now I like to investigate the possibilities of working together with other partner schools by making use of Web2.0 applications such as DimDim ${ }^{\mathrm{TM}}$." (educator 4)

Analysis of the literature on TPD and participants' data leads to the realization of the significance of developing adequate TPD programs using transformative learning theory. In Mezirow and Cranton's view, critical reflection 
is central to transformative learning. Engaging educators in reflecting on their profession, content and process enables them to construct a vision of themselves "as facilitators rather than teachers” [15, p.4].

During several workshops, I experienced as facilitator, transformative learning becoming a distinctive process. The workshop activities led the participants in acquiring new knowledge, skills, or beliefs and values. Moreover, they were able to revise their beliefs and assumptions with regard to their perspective of their profession or their view of technology in education. One particular quotation from Mezirow[22] captures my understanding of transformational learning and its significance in TPD programs:

Transformative learning refers to transforming a problematic frame of reference to make it more dependable in our adult life by generating opinions and interpretations that are more justified. We become critically reflective of those beliefs that become problematic ... Frames of reference may be highly individualistic or shared as a paradigm.Transformational learning is a way of problemsolving by defining a problem or by redefining or reframing the problem. [22, p.20]

\section{IMPLICATIONS FOR EDUCATIONAL PRACTICE}

The theoretical review and the focus group interview in this study suggest that transformative learning theory has significant implications for educators' technology professional development. It is important for educators to act on new assumptions and beliefs about their own teaching practice. As has been discussed earlier, critical reflection is a central process in transformative learning [13]. In other words, transformative learning can shed light on the nature of reflection which, in turn, can provide a useful framework for educators in order to question their teaching and learning. For example, recognizing dimensions of reflection (content reflection, process reflection, premise reflection) based on Mezirow's [26] transformative learning theory will support educators' technology professional development. For educators this suggests, that it is important to engage in critical reflection through critical peer dialogue. By making use of teaching portfolios or journals that other trusted peers can providewith critical comments, suggestions and recommendations, educators may achieve new growth in their personal and technology professional development.

Additionally, experimentation with practice creates possibilities to reflect on learning and increases selfawareness since the educator is able to question, to reflect on, and create alternatives to improve his or her teaching with emerging technologies. This implies that selfawareness is an important ingredient for professional development. Moreover, group activities that encourage educators to "think in a critical way about their teaching from a different angle" as well as "to imagine teaching in a different way is helpful” [13]. Suggestions could be: (1) creating discussion groups or critical peer groups that meet on a regular basis to exchange views, experiences or best practices with regard to ICT knowledge and skills, (2) creating pairs which consist of a novice and expert and in which the expert functions as a buddy. Engaging educators "in dialogue should not be to be fixed or saved, but rather to be seen and heard” [15, p.192].

In sum, there is no standard format with respect to what technology professional development activities serves best, but it is clear that educators need to discuss their views, beliefs, assumptions and practice with regard to emerging technologies. Dialogue plays an important role in transformative learning [22] which fosters technology professional development.

\section{CONCLUSION AND FURTHER RESEARCH}

Emerging technologies are being introduced in educational contexts at such a rapid rate today that it is difficult for educators to keep up. Moreover, as society and the education community realize the need to integrate ICTs in education, the need for TPD becomes more and more essential in the transformation of education.

This paper examined the literature on TPD and considered the current state of TPD for educators in higher education and described efforts to improve the situation based on Mezirow [9] and Cranton's[15] transformative learning theory. This theory reveals changes educators can experience with regard to their practices and provides insight in and a better understanding of how to develop adequate TPD programs for educational purposes. Additionally, it affirms that the human element in the transformation of education and the implementation of ICTs in the classroom cannot be overemphasized or, as Scheingold [50] puts it:

The challenge of integrating technology into schools and classrooms is much more human than it is technological ... it is not fundamentally about helping teachers to operate machines. Rather it is about helping people primarily, teachers, integrate these technologies into their teaching as tools of a profession that is redefined through theincorporation process. [50, pp.17-27]

Helping educators to use ICTs effectively in the classroom may be the most important step "to assuring that current and future investments in [educational] technologies are realized" [51, p.2], the benefits of using emerging technologies in teaching and learning are enormous. However, the emphasis should be on the human element, the educator, and not only on the technological.

In her research, Hawkins [52] states that there are several factors which are of equal importance in creating technology-using educators. Her words reflect the ideas, views and experiences of many educators and researchers in the challenging endeavor called TPD:

Intensive sessions where teachers are able to explore new ideas and materials; follow-up support over an extended period of time with mentors ... ongoing, reflective conversations with colleagues doing the same job and trying to make similar change; and observations of other teachers, both for exemplary practice and observing the process of change. [52, p.215]

Although literature makes clear that transformative learning theory will result in improvement of TPD programs for educators, it is not often put into practice in a well-articulated manner. Using transformative learning theory as a format or model to develop TPD programs is a nontrivial matter. In other words, more research needs to be done to provide effective TPD for educators in higher education.

In my role as an e-learning coordinator and as a lecturer, I experience on a daily basis that many colleagues feel isolated and without adequate support or challenge from others within the organization. Although the number of empirical studies is increasing, there is still much that is 
not known about transformative learning and its supportive role in educational technology professional development programs. In order to come to grips with this undesirable and inefficient situation I am very interested in adopting an action research approach to studying the ways in which educators "experience, conceptualize and perceive” professional development [53, p.57].

\section{ACKNOWLEDGMENT}

The author would like to thank Dr. Geert van Iersel for proof-reading the manuscript and giving helpful advice.

\section{REFERENCES}

[1] Sachs, J., "Teacher professional identity: competing discourses, competing outcomes.”Journal of Education Policy, 16, pp. 149161, 2001. http://dx.doi.org/10.1080/02680930116819

[2] Robinson B., \&Latchem C., "Teacher Education: Challenges and Change,” inTeacher Education through Open and Distance Learning, Robinson, B \&Latchem, C, Eds. London: RoutledgeFalmer, 2003, pp. 1-27.

[3] King, P., "Educational Technology Professional Development as Transformative Learning Opportunities.”Computers and Education, 39, pp. 221-243, 2002. http://dx.doi.org/10.1016/S03601315(02)00073-8

[4] Schrum, L., “TPD for Teachers.”Educational Technology Research and Development, 47, pp. 83-90, 1999. http://dx.doi.org/ 10.1007/BF02299599

[5] Robyler, M., \& Edwards, J., Integrating Educational Technology into Teaching. Upper Saddle River NJ: Prentice Hall, 1999.

[6] Geisert, P., \&Futrell, M., Teachers, Computers, and Curriculum: Microcomputers in the Classroom. Boston: Allyn and Bacon, 2000.

[7] Jonassen, D., Computers and Mindtools for Schools: Engaging Critical thinking. Upper Saddle River NJ: Merrill-Prentice Hall, 2000.

[8] Fullan, M., \&Stiegelbauer, S., The New Meaning of Educational Change. New York: Teachers College Press, 1991.

[9] Mezirow, J., Education for Perspective Transformation; Women's Re-entry Programs in Community Colleges. New York: Teachers College, 1978.

[10] Pallof, R., \& Pratt, K., Building Learning Communities in Cyberspace. San Francisco: Jossey-Bass, 1999.

[11] Sachs, J., The Activist Teaching Profession. Buckingham: Open University Press, 2003.

[12] Brookfield, S., Becoming a Critically Reflective Teacher. San Francisco: Jossey-Bass, 1995.

[13] Cranton, P., Professional Development as Perspective Transformation. San Francisco: Jossey-Bass, 1996.

[14] Lawler, P., \& King, P., Planning for Effective Faculty Development; using Adult Learning Strategies. Malabar FL: Krieger, 2003.

[15] Cranton, P., Understanding and Promoting Transformative Learning: A Guide for Educators of Adults. San Francisco: JosseyBass, 2006.

[16] King, P., "Both Sides Now: Examining Transformative Learning and Professional Development of Educators."Innovative Higher Education, 29, p.155, 2004. http://dx.doi.org/10.1023/B:IHIE. $0000048796.60390 .5 \mathrm{f}$

[17] Honey, M., \&Henriquez, A., Telecommunications and K-12 Educators: Findings from a National Survey. New York: Bank Street College of Education, 1993.

[18] Mehlinger, H., “The next step.”Electronic School, A22-A24, 1997.

[19] Cuban, L., "Computers meet Classrooms: Classroom wins.” Teacher College Records, 95pp.185-210, 1995.

[20] Cuban, L., Oversold and Underused: Computers in the Classroom. Cambridge MA: Harvard University Press, 2001.

[21] Macmillan, R., Liu, X., \& Timmons, V., “Teachers, Computers, and the Internet: The First Stage of a Community-Initiated Project for the Integration of Technology into the Curriculum.” The Alberta Journal of Educational Research, 53, pp.222-234, 1997.

[22] Mezirow, J., Learning as Transformation. San Francisco: JosseyBass, 2000.

[23] Hughes, J., "The Role of Teacher Knowledge and Learning Experiences in Forming Technology-Integrated Pedagogy.” Journal of Technology and Teacher Education, 13, pp.277-302, 2005.

[24] Mezirow, J., "Understanding Transformation Theory." Adult Education Quarterly, 44, pp.222-223, 1994. http://dx.doi.org/ $10.1177 / 074171369404400403$

[25] Dewey, J., How we think. New York: Heath, 1933.

[26] Mezirow, J., Transformative Dimensions of Adult Learning. San Francisco: Jossey-Bass, 1991.

[27] Cranton, P., Transformative Learning in Action: Insights from Practice, New Directions in Adult and Continuing Education. San Francisco: Jossey-Bass, 1997.

[28] Merriam, S., \&Caffarella, R., Learning in Adulthood. San Francisco: Jossey-Bass, 1999.

[29] Taylor, W., “An Update of Transformative Learning Theory: A Critical Review of the Empirical Research (1995-2005).” International Journal of Lifelong Education, 26, pp.173-1991, 2007. http://dx.doi.org/10.1080/02601370701219475

[30] Dirkx, J., "Transformative Learning and the Journey of Individuation.” Clearinghouse Digest, No. 223, (ERIC Documentation Reproduction Service No. 448305), 2000.

[31] Jarvis, C., "Desirable Reading: The Relationship between Women Students' Lives and their Reading Practices.” Adult Education Quarterly, 53, pp.261-276, 2003. http://dx.doi.org/10.1177/074 1713603254029

[32] Lange, E., "Transformative and Restorative Learning: A Vita Dialectic for Sustainable Societies.” Adult Education Quarterly, 54, pp.121-139. http://dx.doi.org/10.1177/0741713603260276

[33] Freire, P., Pedagogy of the Oppressed. New York: Continuum, 1984.

[34] Boyd, R., \& Meyers, J., “Transformative Education.” International Journal of Lifelong Education, 7, pp.261-284, 1988. http://dx.doi.org/10.1080/0260137880070403

[35] Cragg, C., Plotnikoff, R., Hugo, K., \& Casey, A., "Perspective Transformation in RN to BSN Distance Education.” Journal of Nursing Education, 40, pp.317-322, 2001.

[36] Liimatianen, L., Poskiparta, M., Karhila, P., \&Sjögren, A., “The Development of Reflective Learning in the Context of Health Counselling and Health Promotion during Nurse Education.” Journal of Advanced Nursing,34, pp.648-658, 2001. http://dx.doi.org/10.1046/j.1365-2648.2001.01794.x

[37] Collis, B., \&Wende M., van der, "Models of Technology and Change in Higher Education, An International Comparative Survey on the Current and Future Use of ICT in Higher Education,” Center for Higher Education Policies Studies, University of Twente, Dec. 2002.

[38] Douglas, J., All globalization is local: Countervailing forces and the influence on higher education markets [online]. Paper CSHE. Berkeley: eScholarship Repository: University of California. Last accessed 25 April 2010 at: http://respositories.cdlib.org/cshe/ CSHE-1-05/

[39] Collis, B., "The Internet as an Educational Innovation, Lessons from Experience with Computer Implementation.” Educational Technology, 36, pp.21-30, 1996.

[40] Cuban, L., Teachers and Machines: The Classroom Use of Technology since 1920, New York: Teachers College Press, 1986.

[41] Bradshaw, L., “Technology-Supported Change: A Staff Development Opportunity.” NAASP Bulletin, 81, pp.86-92, 1997. http://dx.doi.org/10.1177/019263659708159311

[42] Holland, P., "Professional Development in Technology: Catalyst for School Reform.” Journal of Technology and Teacher Education, 9, pp. 245-267, 2001.

[43] Becker, H., (1999). Internet Use by Teachers: Conditions of Professional Use and Teacher-Directed Student Use[Online], Center for Research on Information Technology and Organizations, University of California. Available: http://www.crito.uci.edu/TLC/FINDINGS/internet-use. 
[44] Evans, R., The Human Side of School Change: Reform, Resistance, and the Real-Life Problems of Innovation. San Francisco: Jossey-Bass, 1996.

[45] Dutch Ministry of Education, Culture and Science, (2005, Oct. 14). Policy Document E-Learning in Higher Education [Online]. Available: http://www.rijksoverheid.nl/ministeries/ocw.

[46] Borko, H., \& Putnam, R., "Learning to Teach,” in Handbook of Educational Psychology, D. Berliner \& R. Calfee, Eds. New York: Macmillan, 1996, pp.673-708.

[47] Hughes, J., "The Role of Teacher Knowledge and Learning Experiences in Forming Technology-Integrated Pedagogy.” Journal of technology and teacher education, 13, pp.277-302, 2005.

[48] Fontys University of Applied Sciences, (2011, June. 15). Educational Vision [Online]. Available: http://fontys.edu/about.fontys/ educational.vision.aspx.

[49] Bransford, J., \& Schwartz, D., "Rethinking Transfer: A Simple Proposal with Multiple Implications.” in Review of Research in Education, A. Iran-Nejad\& P. Pearson, Eds. Washington, DC: American Educational Research Association, 1999, pp.61-100.

[50] Scheingold, K., "Restructuring for Learning with Technology: The Potential for Synergy.” Phi Delta Kappan, 73, pp.17-27, 1991.
[51] Office of Technology Assessment (OTA), (1995). Teachers and Technology: Making the Connection (OTA-HER-616). Washington, DC: U.S. Government Printing Office.

[52] Hawkins, J., "Imagine the Possibilities: The World at Your Fingertips.” in Learn \& Live, P. Burnes\& W. Snider, Eds. Nicasio, CA: The George Lucas Educational Foundation, 1997, pp.212215

[53] Dall’Allba, G., Walsh, E., Bowden, J., Martin, E., Marton, F., Ramsden, P., \&Stephanou, A., "Assessing Understanding: A Phenomenographic Approach.” Research in Science Education, 19, pp.57-66, 1989. http://dx.doi.org/10.1007/BF02356846

\section{AUTHOR}

M. E. M. Schols is a lecturer and doctorate student with Fontys University of Applied Sciences, Tilburg, The Netherlands (e-mail: m.schols@fontys.nl).

Submitted, July, 26, 2011. Published as resubmitted by the author on Oktober 20, 2011. 